\title{
Ortaöğretim Öğrencilerinin Psikolojik İyi oluşlarının Yordayıcısı Olarak İyimserlik-Kötümserlik Düzeyi ve Dini Yönelimler
}

\author{
DOI: 10.26466/opus.734018
}

\author{
Hasan Bozgeyikli* - Mustafa Çalışkan ** \\ * Prof. Dr., Selçuk Üniversitesi, Eğitim Fakültesi, Konya/Türkiye \\ E-Posta: hbozgeyikli@selcuk.edu.tr \\ ORCID: 0000-0002-6762-1990 \\ ** Doktora Öğrencisi, Ondokuz Mayıs Üniversitesi, Sosyal Bilimler Enstitüsü, Samsun/Türkiye \\ E-Posta: caliskan5542@hotmail.com \\ ORCID: 0000-0001-7589-895X
}

\section{$\ddot{O} z$}

Ortaöğretim öğrencilerinin iyimserlik-kötümserlik düzeyleri ile dinî yönelimlerinin psikolojik iyi oluş düzeylerinin anlamlı bir yordayıcısı olup olmadığını test etmeyi amaçlayan bu çalışmada genel tarama modeline dayalı ilişkisel tarama modeli kullanılmıştır. Bu çalışmanın evrenini 2019-2020 eğitim öğretim yılında Samsun Il Milli Eğitim Müdürlüğ̈̈'ne bağhl ortaöğretim okullarında öğrenim gören lise öğrencileri oluşturmaktadır. Araştırmanın örneklemi tesadüfi örneklem yöntemiyle seçilen 472 öğrenci-den oluşmaktadır. Araştırma verilerini elde etmek için kişisel bilgi formu "Din̂̂ Yönelim Ölçeği, Psikolojik İyi Oluş Ölçeği ve Ergenlerde İyimserlik-Kötümserlik Ölçeği" kullanılmıştır. Verilerin analizinde betimsel istatistikler, pearson momentler çarpımı korelasyon tekniği ve doğrusal regresyon analiz tekniği kullanılmıştır. Araştırmanın bulgularına göre psikolojik iyi oluş ile iyimserlik arasında pozitif yönlü, kötümserlik ile ise negatif yönlü anlaml bir ilişki bulunmaktadır. Bununla birlikte psikolojik iyi oluş ile içsel, katı kuralcı ve dışsal dinî yönelim arasında pozitif yönlü anlamlı bir ilişki tespit edilmiştir. Ayrıca psikolojik iyi oluş ile sorgulayıcı din̂̂ yönelim arasındaki ilişki düzeyi manidar bulunmamıştır. İyimserlik ve kötümserlik ile din̂े yönelim ölçeği alt boyutlarının birlikte psikolojik iyi oluşu yordama düzeyine ilişkin bulgulara göre iyimserlik düzeyinin psikolojik iyi oluşun en güçlü yordayıcısı olduğu tespit edilmiştir. Bununla birlikte dışsal dinî yönelim alt boyutunun da psikolojik iyi oluşun anlamlı bir yordayıcısı olduğu, kötümserlik ve diğger dinî yönelimlerin ise psikolojik iyi oluşu yordama düzeyinin manidar olmadığı sonucuna ulaşılmıştır. Elde edilen sonuçlara gore önerilerde bulunulmuştur.

Anahtar Kelimeler: Ortaöğretim öğrencileri, İyimserlik-Kötümserlik, psikolojik iyi oluş, Dini yönelim 


\title{
Religious Orientations and Optimism-Pessimism Level as Predictors of Secondary School Students' Psychological Well-Being
}

\begin{abstract}
Relational screening model based on general screening model was used in this study, which aims to test whether the optimism-pessimism levels and religious orientation of secondary school students are a significant predictor of psychological well-being levels. The working universe of the research is high school students studying in secondary schools affiliated to Samsun Provincial Directorate of National Education in the 2019-2020 academic year. The sample of the study consists of 472 students selected by simple random element sampling method. In order to collect research data, personal information form "Religious orientation scale, Psychological well-being scale and Optimism-Pessimism Scale in Adolescents" were used. In addition to descriptive statistics, pearson moments product correlation technique and linear regression analysis technique were used in the analysis of the data. According to the findings obtained from the research, there is a positive relationship with psychological well-being and optimism and a negative relationship with pessimism. In addition, it has been determined that there is a positive relationship between psychological well-being and inner religious orientation, strict normative religious orientation and external religious orientation. On the other hand, the level of relati-onship between psychological well-being and questioning religious orientation was not significant. According to the findings related to the predictive level of the sub-dimensions of optimism, pessimism, and religious orientation scale, the level of optimism is the strongest predictor of psychological well-being. In addition, it was concluded that the sub-dimension of external religious orientation is a signifi-cant predictor of psychological well-being, and the level of predicting that pessimism and other religi-ous orientations are psychological well-being is not significant. Suggestions were made based on the findings obtained from the research.
\end{abstract}

Keywords: Secondary school students, Optimism-Pessimism, psychological well-being, Religious orientation 


\section{Giriş}

İyilik kavramı; iyi olma durumu, yaşam standardı, yaşam doyumu ve mutluluk gibi terimlerle açıklanmıştır (Foster ve Keller, 2008). Bu terimlerden iyi olma, deneyim ve işlevselliği içeren karmaşık bir yapı olarak bireylerin potansiyellerini geliştirebilme, verimli ve yaratıcı çalışabilme, güçlü ve olumlu kişilerarası ilişkiler kurabilme durumu olarak tanımlanmaktadır (Cross ve Jenkins, 2009). İyi oluş teriminin psikolojiye etki düzeylerinin araştırılması ve literatüre girmesi 20.yüzyılın ikinci yarısına denk gelmektedir. Bradburn (1969) psikolojik iyi oluş kavramın ilk kez "The Structure of Psychological Well-Being" adlı eserinde kullanılmıştır. Fakat araştırmaları ile psikolojik iyi oluş kavramına katkı yaparak, günümüzde kullandığımız tanıma şeklini veren kişi ise Amerikalı psikolog Carol D. Ryff'tır (Ryff, 1989).

Günümüzde psikolojik iyi oluş; bireyin kendini ve geçmiş yaşantılarını olumlu değerlendirmesine, bir birey olarak büyüme ve gelişme hissine, yaşamının amaca ve anlama sahip olduğu duygusuna, başkalarıyla kaliteli ilişkilere sahip olmasına, çevresini etkili bir şekilde yönetmesine ve kendi kararların kendisinin vermesine ilişkin yaptığı bütüncül bir değerlendirme olarak ifade edilmektedir (Küçü, 2018). Bireylerin yaşamdan beklentilerini, potansiyelinin farkında olup olmadığını, diğer bireylerle ilişkisinin kalitesini ve bireyin sahip olduğu potansiyeli tam olarak kullanabilme yeteneği olarak da ifade edilebilen psikolojik iyi oluş düzeyinin yüksek olmasının, bireyin hayatını her yönden olumlu etkileyeceği söylenebilir (Polatcı, 2011).

Psikolojik iyi oluşun hangi değişkenleri yordadığı üzerine çeşitli araştırmalar yapılmıştır. Bu araştırmalardan birinde Maltby, Lewis ve Day (1999) içsel, dışsal, sorgulayıc dinî yönelim değişkenlerinin psikolojik iyi olmayla ilişkisini araştırdığı çalışmada en çok içsel dinî yönelimin psikolojik iyi olmayı yordadığını bulmuşlardır. Bu sonuçda bize göstermektedir ki psikolojik iyi oluşu etkileyen değişkenlerden biride dinî yönelimdir.

Din insanlık tarihinde bireyler ve toplumlar nazarında önemli bir yere sahip olmuştur. Bireylerin insanüstü bir kuvvet karşısındaki ihtiyaç, istek, sığınma, inanç, duygu, ilham ve dua gibi çeşitli tezahürlerinin ve iç yaşayışlarının bütünü olarak tanımlanmaktadır (Dinç, 2007). Farklı din tanımlarının yapılmış olmasına rağmen tanımlardaki ortak nokta, dinin insanın içindeki psikolojik atmosferin ve kendi dişındaki toplumsal atmosferin hangi yönde eğilim gösterdiği üzerinde durmaktadır (Ayten, 2004). Sosyal psiko- 
lojinin, bağımsız bir disiplin olarak ortaya çıktı̆̆ 20. yüzyılın ilk yarısından itibaren, üzerinde durduğu önemli hususlardan biri yönelim konusudur. 1930'lu yıllarda Gordon Allport yönelimi şöyle tarif etmiştir; kişinin çevresinde bulunan varlıklara ve durumlara vereceği tepki üzerinde canlı bir etkiye sahip deneyimler yoluyla şekillenmiş, düşünsel ve doğal hazır oluş halidir (Onay, 2004). Bu tanım ile yönelim kelimesi bireysel yönelim, toplumsal yönelim, dinî yönelim gibi çeşitli şekillerde tanımlanmaya başlanmiştır.

Bu değişkenlerden dinî yönelim; kişinin dinî inanç ve değerlerini uygulama veya yaşama biçimidir (Batson, Schoenrade ve Ventis, 1993). Literatürde dinî yönelim içsel, dışsal, sorgulayıcı ve katı kuralcı olarak dört biçimde ifade edilmektedir. Bireylerin dinî yaşamında motive edici kaynaklarla ilgili yaklaşımların tespit edilmesi dinî yönelim biçiminin anlaşılmasinda etkendir (Erdoğan, 2014). Bireylerin hayatında önemli bir yere sahip olmaya başlayan dinî yönelim 20.yüzyılın sonlarından itibaren üzerinde çalışılan bir konu olmuştur. Yapılan çalışmalarda dindarlığın boyutları belirlenirken bireylerin hayata ve olaylara dair beklentileri, iyimser veya kötümser tavır takınmalarında önemli rol oynadığı söylenebilir. Bu noktada din ile iyimserlik arasındaki bă̆, din-psikoloji ilişkisine benzemektedir.

Dinî yönelimde önemli etkenlerden biri olan iyimserlik kavramı; içinde yaşanılan şartlardan bağımsız sürekli ve tutarlı şekilde bireylerin yaşamında olumlu sonuçlarla karşılaşma eğilimidir (Scheier ve Carver, 1992). İyimserlik kavramının zıttı olarak kötümserlik ise bireylerin yaşamlarında olumsuz durumlar ile karşılaşacaklarına dair bir tutum içinde olmaları şeklinde tanımlanmaktadır (Çalışkan ve Uzunkol, 2018).

İyimserliğin tarih sahnesine çıkışı ise 1700'lü yıllarda Leibniz tarafından, bir düşünce biçimi olarak tanımlanması ile olmuştur. Voltaire, Candide romanı ile bu kavramı popüler bir hale getirmiştir. Eserinde Voltaire, iyimser bakış açısının sığlığının eleştirisini yapmıştır. Kötümserlik ise ilginç bir şekilde bir asır sonra Schopenhauer ve Coleridge tarafından tanımlanmıştır (Öztürk, 2013). Bu süreçte tarihi gelişiminden ziyade bireyler üzerindeki etkileri ne düzeyde olduğu önemsenmiştir. Kritik aşamalarda farklı stratejiler kullanma açısından iyimserler ve kötümserlerin tutumlarında farklı tepkiler önplana çıkmaktadır. İyimser bireyler, gelecek yaşamları hakkında kendilerine çok güvenmeleri sebebiyle, önemli zorluklara karşı mücadele ederek hedefe ulaşmaya çalışırlar. Kötümser bireyler ise gelecek yaşamları 
hakkında şüpheci yapılarından, zorlu yaşam koşullarını ve varlıklarını yok sayarak mücadeleden kaçarlar.

$\mathrm{Bu}$ noktalardan hareketle araştırmada öğrencilerin psikolojik iyi oluşlarının yordayıcısı olarak iyimserlik-kötümserlik düzeyi ve dinî yönelimlerin anlamlılığı önemli sayılmış ve araştırmanın amacını oluşturmuştur.

Araştırmanın genel amacına ulaşmak amacıyla aşağıdaki soruların cevabi aranmıştır.

1. Ortaöğretim öğrencilerinin psikolojik iyi oluş, dinî yönelim ve iyimserlik-kötümserlik düzeyleri arasında anlamlı bir ilişki var mıdır?

2. Ortaöğretim öğrencilerinin iyimserlik-kötümserlik düzeyleri ile dinî yönelimleri psikolojik iyi oluşlarını anlamlı düzeyde yordamakta midir?

\section{Yöntem}

\section{Araştırmanın Modeli}

Ortaöğretim öğrencilerinin iyimserlik-kötümserlik düzeyleri ile dinî yönelimlerinin psikolojik iyi oluş düzeylerinin anlamlı bir yordayıcısı olup olmadığını test etmeyi amaçlayan bu araştırmada genel tarama modeline dayalı ilişkisel tarama modeli kullanılmıştır. Araştırmada ilk olarak öğrencilerin iyimserlik-kötümserlik düzeyleri, psikolojik iyi oluş düzeyleri ve dinî yönelimleri arasındaki ilişki düzeyi incelenmiştir. Daha sonra iyimserlikkötümserlik düzeyleri ile dinî yönelimlerinin öğrencilerin psikolojik iyi oluş düzeylerini anlamlı düzeyde yordayıp yordamadığına bakılmıştır.

\section{Çalışma Grubu}

Bu araştırmanın genel evrenini 2019-2020 eğitim- öğretim yılında Samsun İl Milli Eğitim Müdürlüğ̈̈'ne bağlı ortaöğretim okullarına devam eden öğrenciler oluşturmaktadır. Basit tesadüfi yöntemle seçilen 472 öğrenci araştırmanın örneklemini oluşmaktadır. Araştırmada örneklem grubuna alınan 472 öğrencinin \%39'u (184 kişi) kı, \%61'i (288 kişi) erkektir. Öğrencilerin \%25,6's (121 kişi) Fen Lisesi, \%25,2'si (119 kişi) Anadolu Lisesi, \%20,6'sı (97 kişi) Anadolu İmam Hatip Lisesi ve \%28,6's1 (135 kişi) Mesleki ve Teknik Anadolu Lisesi öğrencisidir. Sınıf düzeyinde ise öğrencilerin \%28,0'1 (132 
kişi) 9.sınıf, \%20,3’ü (96 kişi) 10.sınıf, \%18,6'sı (88 kişi) 11.sınıf ve \%33,1'i (156 kişi) 12. sınıf düzeyindedir.

\section{Veri Toplama Araçları}

$\mathrm{Bu}$ araştırmanın verilerini öğrencilerin demografik yapılarını tespit etmek amacıyla araştırmacılar tarafından hazırlanmış olan form kullanılmıştır. Ayrıca öğrencilerin dinî yönelimlerini belirlemek amacıyla içsel, katı kuralcı, dışsal ve sorgulayıcı dinî yönelim şeklinde dört faktörü içeren "Dinî Yönelim Ölçeği", psikolojik iyi oluş düzeylerini saptamak için "Psikolojik İyi Oluş ölçeği", iyimserlik-kötümserlik düzeylerini ise "Ergenlerde İyimserlikKötümserlik ölçeği" kullanılarak tespit edilmiştir.

Kişisel bilgi formu: Verilerin elde edilmesinde öğrencilerin, cinsiyeti, sınıf düzeyi, anne-baba eğitim düzeyleri ve öğrenim gördükleri okul türlerini de kapsayan demografik özelliklerinide belirlemek amacıyla kullanılmıştır. Bu form araştırmacılar tarafından hazırlanmıştır.

Dinî yönelim ölçeği: Bu araştırmada öğrencilerin dinî yönelimlerini belirlemek amacıyla Ercan (2009) tarafından geliştirilen "Yeniden Yapılandırılmış Müslüman Dinî Yönelim Ölçeği (Dinî Yönelim Ölçeği)" kullanılmıştır. Dinî yönelim ölçeği 21 maddeden oluşmaktadır. Bu ölçeğin 4 alt boyutu bulunmaktadır. Ölçeğin amacı bireyin dine bakış açısı ve dinî tutumlarını anlamlandırma tarzını belirlemektir. Dinî yönelim ölçeği yapı geçerliği çalışmaları kapsamında faktör analizine uygunluğu için KMO ve Barlett testi hesaplamaları yapılmıştır. Çalışmada KMO örneklem uygunluk katsayısı .94 bulunmuştur. Verilerin faktör analizi sonucunda KMO değerinin uygun olduğu bulunmuştur. Ölçeğin yapı geçerliğini tespit etmek amacıyla yapılan açıklayıcı faktör analizi (AFA) sonucunda 4 alt ölçek elde edilmiştir. Bunlar içsel, katı kuralcı, dışsal ve sorgulayıcı dinî yönelimdir.

Dinî yönelim ölçeğinin güvenirlik çalışması kapsamında ölçeğin maddelerinin iç tutarlığını tespit eden Cronbach Alpha katsayısı hesaplanmıştır. Cronbach Alpha katsayısı ölçeğin alt ölçeklerinden içsel dinî yönelim (IDY) .93, dişsal dinî yönelim (DDY) .83, sorgulayıcı dinî yönelim (SDY) .73, katı kuralcı dinî yönelim (KKDY) .81 olarak bulunmuştur. Ölçeğin güvenirliği 
kapsamında yapılan tüm bu analizler ölçeğin güvenirliğinin yeterli düzeyde olduğunu göstermektedir.

Psikolojik iyi oluş ölçeği: Öğrencilerin psikolojik iyi oluş düzeylerini belirlemek amaciyla Diener, Wirtz, Tov, Kim-Prieto, Choi, Oishi ve BiswasDiener (2010) tarafından geliştirilen ve Telef (2013) tarafından Türkçéye uyarlaması yapılan "Psikolojik iyi oluş ölçeği" kullanılmıştır. Sekiz maddeden oluşan ölçeğin her bir maddesi "Kesinlikle katılmıorum (1)" ile "Kesinlikle katılıyorum (7)" arasında puanlanmaktadır. Ölçekten en düşük 8, en yüksek 56 puan alınmaktadır. Ölçekten alınan yüksek puan bireyin pek çok psikolojik kaynağa sahip olduğunu ifade etmektedir. Açklayıcı faktör analizine göre toplam açıklanan varyansın $\% 41,94$ olduğu belirlenmiştir.

Ölçeğin güvenirlik Cronbach Alfa iç tutarlılık katsayısı .80 olarak hesaplanmıştır. Test tekrar test sonucunda ölçeğin uygulamalarında yüksek düzeyde, pozitif yönlü ve anlamlı ilişki tespit edilmiştir ( $r=.86, \mathrm{p}<.001)$. Psikolojik iyi oluş ölçeği'nin madde korelasyonlarının .41 ile .63 arasında olduğu ve t-değerlerinin anlamlı olduğu görülmüştür ( $p<.001)$. Psikolojik iyi oluş ölçeği'nin iç tutarlık katsayısı .827 olarak hesaplanmıştır.

Ergenlerde İyimserlik Kötümserlik Ölçeği: Gençlerin iyimserlik ve kötümserlik düzeylerini belirlemek amacıyla Çalışkan ve Uzunkol (2018) tarafından geliştirilen "Ergenlerde İyimserlik-Kötümserlik ölçeği" kullanılmıştır. Ölçek geliştirme sürecinde yapılan AFA sonucuna göre toplam varyansın \%43,24'ünü açklamaktadır. DFA sonucuna gore model uyum indekslerinin iyi düzeyde karşılandığından yapının hem kuramsal hemde istatistiksel açıdan da uygunluğu doğrulanmıștır.

Ölçeğin Cronbach Alfa güvenirlik katsayıları iyimserlik .86, kötümserlik .82 olarak saptanmıştır. Ölçek 8 madde iyimserlik ve 8 madde kötümserlik olmak üzere iki faktörlü 16 maddeden oluşmaktadır. Ölçekte dereceleme olarak "Hiç uygun değil" (1), ile "Tamamen Uygun (5)" şeklinde 5'li likert dereceleme kullanılmaktadır. Ölçekteki alt faktörlerden alınan yüksek puanlar ilgili boyutta yüksek bir düzeyi ifade etmektedir. 


\section{Verilerin Toplanması ve analizi}

Çalışmanın veri analizinde betimsel istatistikler ve araştırmanın bağımlı değişkeni (psikolojik iyi oluş) ile bağımsız değişkenleri (iyimserlikkötümserlik ve dinî yönelimler) arasındaki ilişki düzeyini belirlemek amacıyla pearson momentler çarpımı korelasyon tekniği kullanılmıştır. Bağımsız değişkenlerin bağımlı değişkeni yordama düzeyini tespit etmek için doğrusal regresyon analizi tekniği kullanılmıştır. Çalışmada anlamlılık düzeyi, 05 olarak tespit edilmiştir.

\section{Bulgular}

Bu kısımda araştırmanın bulguları sunulmuş ve yorumlanmıştır. Bu kapsamda Ortaöğretim öğrencilerinin psikolojik iyi oluşlarının dinî yönelimler ile iyimserlik-kötümserlik düzeyleri arasındaki ilişkiyi gösteren Tablo 1'deki pearson korelasyon değerleri incelendiğinde psikolojik iyi oluş ile iyimserlik arasında pozitif yönlü anlamlı düşük bir ilişki $(\mathrm{r}=, 647, \mathrm{p}<, 05)$ bulunurken aynı durum psikolojik iyi oluş ile kötümserlik $(\mathrm{r}=, 154 \mathrm{p}<, 05)$ arasında da gözlenmektedir.

Tablo 1. Ortaöğretim Öğrencilerinin Psikolojik İyi Oluşlarının, Din̂̂ Yönelimler ile İimserlik-Kötümserlik arasındaki ilişki düzeyi

\begin{tabular}{|c|c|c|c|c|c|c|c|c|}
\hline & & 1 & 2 & 3 & 4 & 5 & 6 & 7 \\
\hline \multirow[t]{2}{*}{ İyimserlik } & $\underline{\mathrm{r}}$ & - & & & & & & \\
\hline & $\mathrm{p}$ & & & & & & & \\
\hline \multirow[t]{2}{*}{ Kötümserlik } & $\underline{\mathrm{r}}$ &,$- 247^{* *}$ & - & & & & & \\
\hline & $\mathrm{P}$ &, 000 & & & & & & \\
\hline \multirow{2}{*}{$\begin{array}{l}\text { Psikolojik } \\
\text { İyi Oluş }\end{array}$} & $\underline{\mathrm{r}}$ &, $647^{* *}$ &,$- 154^{* *}$ & - & & & & \\
\hline & $\bar{p}$ & 000 & 001 & & & & & \\
\hline \multirow{2}{*}{$\begin{array}{l}\text { İçsel Dinî } \\
\text { Yönelim (IDY) }\end{array}$} & $\mathrm{r}$ & $181^{* *}$ & $112^{*}$ & $240^{* *}$ & - & & & \\
\hline & $\mathrm{p}$ & 000 & 015 & 000 & & & & \\
\hline \multirow[t]{2}{*}{ Katı Kuralcı Dinî Yönelim (KKDY) } & $\underline{\mathrm{r}}$ &, $147^{* *}$ &, $196^{* *}$ & $255^{* *}$ &, $517^{* *}$ & - & & \\
\hline & $\mathrm{p}$ & 001 & 000 & 000 & 000 & & & \\
\hline \multirow[t]{2}{*}{ Dışsal Dinî Yönelim (DDY) } & $\mathrm{r}$ & ,075 & $255^{* *}$ & $226^{* *}$ & $619^{* *}$ & $666^{* *}$ & - & \\
\hline & $\mathrm{p}$ & ,104 &, 000 &, 000 & 000 &, 000 & & \\
\hline \multirow[t]{2}{*}{ Sorgulayıcı Dinî Yönelim (SDY) } & $\mathrm{r}$ & , 086 &, $124^{* *}$ & , 042 &, $121^{* *}$ &,$- 219^{* *}$ & ,051 & - \\
\hline & $p$ & ,063 & 007 & ,366 & ,009 & ,000 & 269 & \\
\hline
\end{tabular}

${ }^{*} \mathrm{p}<, 05 ;{ }^{* *} \mathrm{p}<, 001$

Psikolojik iyi oluş ile İDY $(\mathrm{r}=, 240, \mathrm{p}<, 05)$, KKDY $(\mathrm{r}=, 255, \mathrm{p}<, 05)$ ve DDY $(\mathrm{r}=, 226, \mathrm{p}<, 05)$ arasında pozitif yönlü düşük bir ilişki gözlenmektedir. Diğer 
taraftan psikolojik iyi oluş ile SDY arasında hesaplanan korelasyon değerinde $(r=, 042, p>, 05)$ anlamlı bir ilişki olmadığı görülmektedir.

Ortaöğretim öğrencilerinin iyimserlik ile dinî yönelim düzeyleri arasındaki ilişkiyi gösteren Tablo 1'deki pearson korelasyon değerleri incelendiğinde iyimserlik ile dinî yönelim arasında negatif yönlü düşük bir ilişki (r=,247, p<,05) bulunmaktadır. İyimserlik düzeyi ile IDY $(r=, 181, p<05)$ ve $\operatorname{KKDY}(\mathrm{r}=, 147, \mathrm{p}<, 05)$ arasında pozitif yönlü düşük bir ilişki gözlenmektedir. Diğer taraftan iyimserlik ile DDY arasında $(\mathrm{r}=, 075, \mathrm{p}>05)$ ve SDY $(\mathrm{r}=, 086, \mathrm{p}>, 05)$ arasında hesaplanan korelasyon değeri ,05 düzeyinde anlamlı bir ilişki olmadığını göstermektedir.

Ortaöğretim öğrencilerinin kötümserlik ile dinî yönelim düzeyleri arasındaki ilişkiyi gösteren Tablo 1'deki pearson korelasyon değerleri incelendiğinde kötümserlik düzeyi ile İDY $(\mathrm{r}=, 112$, p<,05), KKDY $(\mathrm{r}=, 196, \mathrm{p}<, 05)$, DDY $(r=, 255, p>, 05)$ ve SDY ( $r=, 124, p>, 05)$ arasında pozitif yönlü düşük bir ilişki gözlenmektedir. Bu veriler kapsamında dinî yönelim değişkenlerinin kötümserlik düzeyinin artmasında etkili bir özellik olabileceği söylenebilir.

Ortaöğretim öğrencilerinin dinî yönelim düzeyleri alt boyutları arasındaki ilişkiyi gösteren Tablo 1'deki pearson korelasyon değerleri incelendiğinde dinî yönelim düzeylerinin alt boyutları arasında IDY ile KKDY $(\mathrm{r}=, 517, \mathrm{p}<, 05)$, DDY $(\mathrm{r}=, 619, \mathrm{p}<, 05)$ ve SDY $(\mathrm{r}=, 121, \mathrm{p}<, 05)$ arasinda pozitif yönlü düşük bir ilişki bulunmaktadır. Ayrıca dinî yönelim alt boyutu KKDY ile DDY $(\mathrm{r}=, 666, \mathrm{p}<0,05)$ ve SDY $(\mathrm{r}=, 219, \mathrm{p}<0,05)$ arasında da pozitif yönlü düşük bir ilişki bulunmaktadır. Diğer taraftan dinî yönelim alt boyutlarında DDY ile SDY arasında hesaplanan korelasyon değerinde $(r=, 051, p>, 05)$ anlamlı bir ilişki olmadığın göstermektedir. Bu veriler ışığında dinî yönelimin alt boyutları düzeyinde DDY ile SDY haricinde diğer boyutlarda az da olsa olumlu yönde birbirini etkilediği söylenebilir.

Ortaöğretim öğrencilerinin iyimserlik-kötümserlik ve dinî yönelimler (IDY, SDY, KKDY, DDY) alt boyutlarından aldıkları puan ortalamalarının, psikolojik iyi oluşlarını açıklama gücüne ilişkin analiz yapılmıştır. Öncelikle iyimserlik-kötümserlik ve dinî yönelimler (IDY, SDY, KKDY, DDY) alt boyutlarının, psikolojik iyi oluşlarını açıklama gücünü tespit etmek için çoklu regresyon analiz yöntemi kullanılmıştır. Elde edilen bulgulara ilişkin sonuçlar Tablo 2'de belirtilmiştir. 
Tablo 2. İyimserlik-Kötümserlik ve Dinî Yönelimler (IDY, SDY, KKDY, DDY) alt boyutlarının, Psikolojik İyi Oluşların açıklama gücü

\begin{tabular}{llllll}
\hline Model & Değisiken & $\mathrm{R}$ & $\boldsymbol{R 2}$ & $\mathrm{F}$ & $\mathrm{P}$ \\
\hline 1 & Kötümser, & & & & \\
& Iyimser, & & & & \\
& IDY &, $675^{\mathrm{a}}$ &, 456 & 64,666 & \\
& SDY & & & \\
& KKDY & & & \\
& DDY & & & & \\
& & & & \\
&
\end{tabular}

${ }^{*} \mathrm{p}<0,05$

İyimserlik-kötümserlik ve dinî yönelimler (IDY, SDY, KKDY, DDY) alt boyutlarının, psikolojik iyi oluşu açılama düzeyini belirlemek amaciyla hesaplanan regresyon katsayısı .675 olarak bulunmuştur. Hesaplanan bu değer iyimserlik-kötümserlik ve dinî yönelimler (IDY, SDY, KKDY, DDY) alt boyutlarının, psikolojik iyi oluşun anlamlı yordayıcları olduğunu göstermektedir. Bu bulguya göre iyimserlik-kötümserlik ve dinî yönelimler (IDY, SDY, KKDY, DDY) alt boyutlarının, psikolojik iyi oluşlarından alınan puanlara ilişkin varyansın \%45,6'sını açıklamaktadır. İyimserlikkötümserlik ve dinî yönelimler (IDY, SDY, KKDY, DDY) alt boyutlarının her birinin psikolojik İyi oluşu açıklama gücüne ilişkin sonuçlar Tablo 3'de belirtilmiştir.

Tablo 3. İyimserlik-Kötümserlik ve Dinî Yönelimler (IDDY, SDY, KKDY, DDY) alt boyutlarının, Psikolojik İyi Oluşların Açıklama Gücü

\begin{tabular}{lllll}
\hline Alt Boyutları & Std. Hata & $\boldsymbol{\beta}$ & $\mathbf{t}$ & $\mathbf{p}$ \\
\hline Sabit & 2,432 & 10,871 & $4,469^{*}$ &, 000 \\
\hline İyimserlik &, 051 &, 832 & $16,426^{*}$ &, 000 \\
\hline Kötümserlik &, 053 &,- 077 & $-1,470$ &, 142 \\
\hline IDY &, 064 &, 014 &, 216 &, 829 \\
\hline KKDY &, 071 &, 119 & 1,675 &, 095 \\
\hline DDY &, 078 &, 195 & 2,4850 &, 013 \\
\hline SDY &, 056 &, 011 &, 194 &, 846 \\
\hline
\end{tabular}

${ }^{*} \mathrm{p}<0,05$

Tablo 3 incelendiğinde psikolojk iyi oluşun en güçlü yordayıcısının iyimserlik düzeyi $(\beta=, 832, p<, 05)$ olduğu görülmektedir. Bununla birlikte DDY alt boyutunun da psikolojik iyi oluşun yordayıcılarından birisi $(\beta=, 832$, $\mathrm{p}<, 05)$ olduğu ancak kötümserlik ile İDY, KKDY ve SDY alt boyutlarının ise 
tek başlarına psikolojik iyi oluşu yordama düzeylerinin anlamlı olmadığı görülmektedir.

\section{Tartışma ve Sonuç}

Ortaöğretim öğrencilerinin psikolojik iyi oluşlarının yordayıcısı olarak iyimserlik-kötümserlik düzeyi ve dinî yönelimler arasındaki ilişkilerin incelendiği bu araştırmada tespit edilen sonuçlara göre psikolojik iyi oluş ile iyimserlik ve kötümserlik arasında pozitif yönlü anlamlı düşük bir ilişki saptanmıştır. Elde edilen sonuclara göre bireylerin iyimserlik ve kötümserlik durumunda meydana gelen artışların, onların psikolojik iyi oluş düzeylerinde de artışa neden olduğu söylenebilir. Benzer bir araştırmada ise Terzi (2008) gerçekleştirdiği bir çalışmada üniversite öğrencilerinin iyimserlik düzeylerinin psikolojik dayanıklılığı yordadığını saptamıştır.

Psikolojik iyi oluş ile İDY, KKDY ve DDY arasında pozitif yönlü düşük bir ilişki gözlenmektedir. Elde edilen bulgulardan psikolojik iyioluş ile SDY arasında anlamlı bir ilişki olmadığı söylenebilir. Araştırmadan elde edilen bu bulgu Göcen (2013)'in "Pozitif psikoloji düzleminde psikolojik iyi olma ve dinî yönelim ilişkisi: yetişkinler üzerine bir araştırma" adlı İstanbul'da yaşayan, yaşları 17-60 arasında değişen 611 yetişkin üzerinde yapmış olduğu çalışmanın buğularınca da desteklenmektedir. Göcen (2013)'in yaptığı çalışmada, psikolojik iyi oluş ve dinî yönelim arasında olumlu bir ilişki olduğu sonucuna ulaşılmıştır. İlgili literatürde yapılmış benzer çalışmalarda da yakın sonuçlar elde edilmiştir. Örneğin Maltby ve diğ. (1999) içsel dinî yönelim, dişsal dinî yönelim, sorgulayıcı dinî yönelimi, kişisel ibadet ve kiliseye katılım değişkenlerinin psikolojik iyi olma ile ilişkisini araştırdığ 1 çalışmada en çok kişisel ibadetlerin ikinci olarak da içsel dinî yönelimin psikolojik iyi olmayı pozitif yönde yordadığı sonucunu bulmuşlardır. Spilka ve Mullin (1977) tarafından lise, üniversite öğrencileri ve çalışanlardan oluşan toplam 689 kişiyle yürüttükleri çalımaya göre içsel bir dinî yönelime sahip bireylerin kendine, başkalarına ve Tanrı'ya yönelik olumlu bir yaklaşım sergiledikleri, dışsal dinî yönelimli bireylerin ise daha az olumlu bir yönelim sergilediklerini saptamışlardır. Buna ilaveten içsel dindarlık yaratıCl, kutsayıcı, haşmetli, merhametli ve hoşgörülü Tanrı anlayışıyla; dışsal dindarlık ise öfkeli ve hiddetli Tanrı anlayışıyla ilişkili olduğu saptanmıştır. Fakat tek boyutlu sonuçların elde edildiği araştırmalardan birinde (Ge- 
nia,1996) ise içsel dinî yönelimin psikolojik iyi oluşun belirgin yordayıcısı olduğu, katı kuralcı dinî yönelim ile psikolojik ve ruhsal iyi oluş arasında da anlamlı bir ilişki bulunmadığı sonucuna ulaşılmıştır. Bahsedilen bu çalışmalarda psikolojik iyi oluş ile dinî yönelim arasında pozitif yönlü bir ilişkinin tespit edilmiş olması, bu araştırmadan elde edilen bulgularla birebir örtüşmektedir.

Araştırmadan elde edilen bulgulardan bir diğeri iyimserlik ile dinî yönelim arasında negatif yönlü düşük bir ilişki bulunmasıdır. Buna göre iyimserlik düzeyi ile IDY arasında pozitif yönlü düşük bir ilişki gözlenmektedir. Diğer taraftan iyimserlik ile DDY arasında anlamlı bir ilişki tespit edilememiştir. Kötümserlik düzeyi ile IDY, KKDY, DDY ve SDY arasında ise pozitif yönlü düşük bir ilişki gözlenmektedir. Bu veriler kapsamında bireylerin iyimserlik ve kötümserlik düzeylerinin dinî yönelimleri ile düşükte olsa bir ilişki gösterdiği söylenebilir.

$\mathrm{Bu}$ araştırmanın diğer bir amacını oluşturan iyimserlik-kötümserlik ve dinî yönelimler (IDY, SDY, KKDY, DDY) alt boyutlarının, psikolojik iyi oluşlarını açıklama düzeyini belirlemek amaciyla hesaplanan regresyon hesaplamasında iyimserlik-kötümserlik ve dinî yönelimler (IDY, SDY, KKDY, DDY) alt boyutlarının, psikolojik iyi oluşlarını anlamlı düzeyde yordadığ1 tespit edilmiştir. Bu bulgulara göre iyimserlik-kötümserlik ve dinî yönelimler (IDY, SDY, KKDY, DDY) alt boyutlarının, psikolojik iyi oluştaki varyansın \%45,6'sını açılamaktadır. Çeçen ve Cenkseven (2007)' in çalışmasinda regresyon analizi sonucunda, toplam varyansın $\% 49^{\prime}$ unu yordadığ görülmüştür. Bu çalışmada üniversite öğrencilerinde yalnızlığın yordayıcısı olarak psikolojik iyi olma halini inceledikleri araştırma sonuçlarına göre öğrencilerin yalnızlı düzeyleri ile psikolojik iyi oluş boyutları arasında anlamlı bir ilişki olduğu saptanmıştır. Aynı şekilde Kapıkıran ve Kapıkıran (2009), psikolojik iyi olmayı yordaması acısından sosyal bağlılık değişkeni açısından incelemişlerdir. Bu çalışmada 350 üniversite öğrencisi ile gerçekleştirilen araştırma bulgularına göre sosyal bağllık ile psikolojik iyi oluşun alt boyutları arasında pozitif yönlü ve anlamlı ilişki olduğu bulunmuştur. Ayrıca sosyal bağllı̆̆g yordayan psikolojik iyi oluş değişkenlerini belirlemek üzere gerçekleştirilen aşamalı regresyon analizi sonucunda kendini kabul, bireysel gelişim ve diğerleri ile olumlu ilişkilerin yordayıcı değişkenler olduğu bulunmuştur. Buna göre bu araştırmadan elde edilen bulguların 
psikolojik iyi oluşun yordayıcıları kapsamında yapılan diğer araştırmaların bulgularıyla benzerlik gösterdiği söylenebilir.

İyimserlik-kötümserlik ve dinî yönelimler (IDY, SDY, KKDY, DDY) alt boyutlarının her birinin psikolojik iyi oluşu açıklama gücüne ilişkin bulgulara göre iyimserlik ve DDY alt boyutları için hesaplanan kısmi korelasyon değerleri psikolojik iyi oluşun anlamlı yordayıcıları olduğunu göstermektedir. İlgili literatür incelendiğinde iyimserlik-kötümserlik ve dinî yönelimler ile psikolojik iyi oluş arasındaki ilişkiyi doğrudan inceleyen bir araştırma olmadığ 1 tespit edilmiştir. Ancak psikolojik iyi oluşun yordayıcılarına ilişkin yapılmış araştırmalar incelendiğinde yordayıcı değişkenler olarak daha çok dişsal faktörlerin incelendiği görülmüştür. Örneğin Cenkseven ve Akbaş (2007) özellikle ergenlik döneminde önem kazanan arkadaşlık ilişkilerinden alınan hoşnutluğun psikolojik iyi oluşu olumlu yönde etkilediğini bulmuşlardır. Cooper, Okamura ve Mcneil (1995) sosyal etkileşimden algılanan doyumun psikolojik iyi oluş ile anlamlı ilişkisi olduğunu belirlemişlerdir. Silva, Horta, Pontes, Faria, Souza, Cruzeiro ve Pinheiro (2007)'nun 960 ergende psikolojik iyi oluş ile ilişkili faktörleri incelediği araştırma sonuçlarına göre psikolojik iyi oluşun sosyo-ekonomik düzeyden etkilendiği, sosyoekonomik düzeyi yüksek aileye sahip ergenlerin psikolojik iyi oluş puanlarının daha yüksek olduğu bulunmuştur. Bir başka araştırmada ortaöğretim öğrencilerinin sosyal ağ kanalları kullanımının psikolojik iyi oluş ile ilişkisi incelenmiştir. 459 öğrenciden veri toplanıldığı araştırmada sosyal ağ kullanımın belirlemek amacıyla öğrencilere "Facebook" ve "Twitter" sosyal ağ kanallarında günlük kullanım süreleri sorulmuş ve psikolojik iyi oluş ölçeği uygulanmıştır. Araştırma sonucunda sosyal ağ siteleri kullanımının psikolojik iyi oluşu anlamlı ve pozitif yönde yordadığı tespit edilmiştir. Başka bir ifadeyle sosyal ağ sitelerinin kullanımı arttıkça öğrencilerin psikolojik iyi oluş düzeyleri de artmaktadır (Doğan, 2016). Bununla birlikte farklı kişilik özelliklerinin psikolojik iyi oluşu yordamasına ilişkin sınırlı da olsa bazı çalışmalar yapılmıştır. Örneğin Doğan, Kaya ve Eren (2016) tarafından yapılan bir araştırmada ortaöğretim öğrencilerinin risk alma davranışları ile psikolojik iyi oluşları arasındaki ilişkisi incelenmiştir. 390 lise öğrencisi ile gerçekleştirilen çalışmada ergenlerde risk alma ölçeği ile psikolojik iyi oluş ölçeği kullanılmıştır. Araştırmanın bulguları ergenlerde risk alma davranışının psikolojik iyi oluşu negatif yordadığı yönündedir. Yine Kermen, İlçin Tosun ve Doğan (2016) tarafından yapılan araştırmanın sonucunda sosyal 
kaygının psikolojik iyi oluşu anlamlı ve negatif yönlü yordadığı bulunmuştur. Ayrıca üniversite öğrencilerinde içsel ve dışsal yaşam amaçlarının psikolojik iyi oluşu anlamlı bir şekilde yordadığı tespit edilmiştir (Cenkseven Önder, Mukba, 2017).

Özetle bu araştırmanın sonuçları öncelikle ortaöğretim öğrencilerinin psikolojik iyi oluşlarının yordayıcısı olarak dinî yönelimler ile iyimserlikkötümserlik düzeyi arasında anlamlı bir ilişki olduğunu ortaya koy-muştur. Bununla birlikte iyimserlik-kötümserlik ve dinî yönelimleri psikolojik iyi oluşu anlamlı düzeyde yordadığı sonucuna ulaşılmıştır. Buna dayalı olarak psikolojik danışma ve rehberlik alanında bireylerin psikolojik iyi oluşlarının arttırılmasına yönelik gerçekleştirilen beceri kazanmaya dönük eğitici programlarda, iyimserlik-kötümserlik ve dinî yönelimlerin dikkate alınmasının programların etkililiğine önemli katkılar sağlayacağı düşünülmektedir. Elbette her çalışmanın kendi içinde bir sınırlılığı bulunmaktadır. Bu çalışmanın da en önemli sinırlılığı ortaöğretim öğrencilerinden oluşan küçük bir örneklem üzerinde gerçekleştirilmiş olmasıdır. Bu kapsamda benzer bir çalışmanın üniversite öğrencileri veya yetişkin gruplar gibi farklı örneklemler üzerinde yapılmasının literatüre önemli katkılar sağlayacağı düşünülmektedir. 


\title{
EXTENDED ABSTRACT
}

\section{Religious Orientations and Optimism-Pessimism Level as Predictors of Secondary School Students' Psychological Well-Being \\ $*$}

\author{
Hasan Bozgeyikli - Mustafa Çalışkan \\ Selçuk University, Ondokuzmayıs University
}

Investigation of the effects of well-being on psychology and its entry into the literature coincides with the second half of the 20th century. The concept of psychological well-being was first used by Bradburn. The person who contributes to the concept of psychological well-being and gives the form of recognition we use today is the American psy-chologist Carol D. Ryff. Since the first half of the 20th century, when social psychology emerged as an independent discipline, one of the important issues that it emphasized is orientation. In the 1930s, Gordon Allport described the orientation. The emergence of optimism on the stage of history was defined as a way of thinking in the 1700s. Pessi-mism was described interestingly a century later.

The level of optimism-pessimism and the significance of religious orientations were considered as the predictors of students' psychologi-cal wellbeing and constituted the purpose of this research.

In order to reach the general purpose of the research, answers to the following questions were sought.

1. Is there a significant relationship between secondary school students' religious orientation, psychological well-being and optimismpessimism levels?

2. Do the optimism-pessimism levels and religious orientation of secondary school students significantly predict their psycholog-ical well-being?

In this study, which aims to test whether the optimism-pessimism levels and religious orientations of secondary school students are a significant predictor of psychological well-being levels, a relational survey model was used. In the study, firstly, the level of relationship between students' opti- 
mism-pessimism levels, psychological well-being levels and religious orientations were examined. Then, it was investi-gated whether optimismpessimism levels and religious orientations significantly predicted the psychological well-being levels of the stu-dents.

The universe of the research consists of secondary school students studying in secondary schools affiliated to Samsun Provincial Direc-torate of National Education in the 2019-2020 academic year. The sam-ple of the study consists of 472 students selected through simple ran-dom sampling method. Of the 472 students included in the research sample, 39\% (184 students) are female and $61 \%$ (288 students) are male.

Personal Information Form developed by the researchers in order to collect the research data was used to determine the gender, class level, education levels of parents and the types of schools they study. In addition, "Restructured Muslim Religious Orientation Scale (Reli-gious Orientation Scale)" developed by Ercan (2009) was used to de-termine the religious orientation of students. The Religious Orientation Scale consists of 21 items and aims to measure the forms of religious orientation of individuals. This scale has 4 subscales: internal religious orientation (IDY), external religious orientation (DDY), strict norma-tive religious orientation (KKDY), and questioning religious orientation (SDY). The aim of the scale is to determine a person's view of religion and the way of making sense of religion.

In order to determine the psychological well-being levels of stu-dents, "Psychological Well-being Scale", which was adapted to Turkish by Telef (2013), was used. The score of the scale, consisting of eight items, ranges from 8 to 56. The high score obtained from the scale indi-cates that the individual has many psychological resources and strengths. "OptimismPessimism Scale in Adolescents" was developed by Çalışkan and Uzunkol (2018) to determine the level of optimism and pessimism of young people. The scale consists of two factors with a total of 16 items; 8 items for optimism and 8 items for pessimism. A five-point Likert grading is used in the scale. High scores from the sub-factors in the scale indicate a high level in the relevant dimension.

In the analysis of the data, in addition to descriptive statistics, Pear-son product-moment correlation technique was used to determine the level of relationship between the independent variables of the research (optimismpessimism and religious orientations) and its dependent variable (psycholo- 
gical well-being). Linear regression analysis tech-nique was used to determine the predictive level of the independent variables. In the study, the level of significance was taken as 05 .

According to the findings of the research, it has been revealed that there is a significant relationship between religious orientations and optimismpessimism level as predictors of psychological well-being of secondary school students. According to the results of the research, there is a low positive relationship between psychological well-being and optimismpessimism. There is a low negative relationship between optimism and religious orientation. A low positive correlation is ob-served between the level of pessimism and IDY, KKDY, DDY, and SDY. There is a low positive correlation between IDY and KKDY, DDY, and SDY among the sub-dimensions of religious orientation levels.

In order to achieve the other purpose of this research, the regres-sion analysis done to reveal whether optimism-pessimism and religious orientations sub-dimensions (IDY, SDY, KKDY, DDY) predict psycho-logical wellbeing concluded that optimism-pessimism and religious orientations subdimensions (IDY, SDY, KKDY, DDY) significantly predicted psychological well-being. According to these findings, the sub-dimensions of religious orientations (IDY, SDY, KKDY, DDY) and optimism-pessimism explains $45.6 \%$ of the variance in psychological well-being.

It is seen that $t$ values calculated for optimism and DDY subscales significantly explain the psychological well-being dimension. The psy-chological well-being of optimism and DDY dimensions seems to have a positive power of explanation.

In summary, the results of this study revealed that there is a signifi-cant relationship between religious orientations and optimism-pessimism level as predictors of the psychological well-being of sec-ondary education students.

\section{Kaynakça / References}

Ayten, A. (2004). Kendini gerçekleştirme ve dindarlık ilişkisi. Yayımlanmamış Yüksek Lisans Tezi, Marmara Üniversitesi, İstanbul.

Batson, C.,D., Schoenrade, P. ve Ventis, W.,C. (1993). Religion and the individual: asocial psychological perspective. Oxford University, New York.

Bradburn, N. M. (1969). The structure of psychological well-being. Chicago: Al-dine. 
Cenkseven Önder, F. ve Mukba, G. (2017). Üniversite öğrencilerinde umut ve psikolojik iyi oluş arasındaki ilişkide yaşam amacının aracı rolü. The Journal Of Academic Social Science Studies, 62, 103-116.

Cenkseven, F. ve Akbaş, T. (2007). Üniversite öğrencilerinde öznel ve psikolo-jik iyi olmanın yordayıcılarının incelenmesi. Türk Psikolojik Danışma ve Rehberlik Dergisi, 3(27), 43-65.

Cooper, H., Okamura, L. ve Mcneil, P. (1995). Situation and personality corre-lates of psychological well-being: Social activity and personal control. Journal of Research in Personality, 29, 395-417.

Cross, S., ve Jenkins R. (2009). Mental capital and wellbeing. European Psychiatric Review, 2(1), 59-61.

Çalışkan, H. ve Uzunkol, E. (2018). Ergenlerde iyimserlik-kötümserlik ölçeğinin geliștirilmesi: Geçerlilik ve güvenirlik çalışması. The Journal of Happiness $\mathcal{E}$ Well-Being, 6(2), 78-95.

Çeçen R. ve Cenkseven F. (2007). Relationships beetween loneliness and psychological well-being among Turkish university students. Çukurova Üniversitesi Sosyal Bilimler Enstitüsü Dergisi, 16 (2), 109-118.

Dinç, A. (2007). Ergenlerde anne-baba tutumları ve dinî yönelim. Yayımlanmamış Yüksek Lisans Tezi, Marmara Üniversitesi, İstanbul.

Doğan, U. (2016). Lise öğrencilerinin sosyal ağ siteleri kullanımının mutluluk, psikolojik iyi oluş ve yaşam doyumlarına etkisi: Facebook ve twitter örneği. Ĕğitim ve Bilim Dergisi, 41(183), 217-231.

Doğan, U., Kaya, S., ve Eren, D. (2016). Lise öğrencilerinin risk alma dav-ranışlarının yaşam doyumu ve psikolojik iyi oluş değişkenleri ile ilişkisi. International Periodical For The Languages, Literature And History Of Turkish Or Turkic, 11(3), 953-964.

Ercan, N. (2009). The predictors of attitudes toward physical wife abuse: Ambivalent sexism, system justification and religious Orientation. Yayımlanmamış Doktora Tezi, Ortadoğu Teknik Üniversitesi, Ankara.

Erdoğan, E. (2014). Tanrı algısı dinî yönelim biçimleri ve dindarlı̆ı̆ psikolojik dayanıkllıkla ilişkisi. Yayımlanmamış Doktora Tezi, Ankara Üniversi-tesi, Ankara.

Foster, L.T. ve Keller, C.P. (2008). British columbia atlas of wellness. Toronto: Distributed for Western Geographical Press.

Genia, V. (1996). I, E, quest, and fundamentalism as predictors of psychologi-cal and spiritual well-being. Journal for the Scientific Study of Religion, 35(1), 56-64. 
Göcen, G. (2013). Pozitif psikoloji düzleminde psikolojik iyi olma ve dinî yönelim ilişkisi: Yetişkinler üzerine bir araştırma. Toplum Bilimleri Dergisi, 7(3), 97130.

Kapıkıran, Ş. ve Kapıkıran, N.A. (2009). Sosyal bağlılığın psikolojik iyi olmayı oluşturan değişkenler bakımından yordanması. XVIII. Ulusal Eğitim Bilimleri Kurultayı. Sözlü Bildiri, Ege Üniversitesi, İzmir.

Kermen, U., İlçin Tosun, N. ve Doğan, U. (2016). Yaşam doyumu ve psikolojik iyi oluşun yordayıcısı olarak sosyal kaygı. Eğitim Kuram Ve Uygulama Araştırmaları Dergisi, 2(2), 20-29.

Kurnaz, M. (2015). Yetişkinlerde dinî yönelim-mutluluk ilişkisi. Yayımlanmamış Yüksek Lisans Tezi, Süleyman Demirel Üniversitesi, Isparta.

Küçü, E. (2018) Lise öğrencilerinde mükemmeliyetçilik, ihtiyaç doyumu ve psikolojik iyi oluş arasındaki ilişkilerin incelenmesi. Yayımlanmamış Yüksek Lisans Tezi, Dokuz Eylül Üniversitesi, İzmir.

Maltby J, Lewis CA. ve Day L. (1999). Religious orientation and psychological wellbeing: The role of the frequency of personal prayer. British Journal of Health Psychology, 4(4), 363-378.

Onay, A. (2004). Dindarlık etkileşim ve değişim. İstanbul: DEM Yayınları.

Öztürk, E. E. (2013). İyimserlik ve dindarlık. Yayımlanmamış Yüksek Lisans Tezi, İstanbul Üniversitesi, İstanbul.

Polata, S. (2011). Psikolojik sermayenin performans üzerindeki etkisinde iş aile yayılımı ve psikolojik iyi oluşun rolü. Yayımlanmamış Doktora Tezi, Erciyes Üniversitesi, Kayseri.

Ryff, C. D. (1989). Happiness is everything, or is it? Explorations on the mean-ing of psychological well-being. Journal Of Personality And Social Psychology, 57(6), 1069-1081.

Scheier, M.F. ve Carver, C. S. (1992). Effect of optimism on psychological and phycical well-being: Theorical over-view and empiral update. cognitive the-raphy and research, 16(2), 201-228.

Silva, R. A., Horta, B. L., Pontes, L. M., Faria, A. D., Souza, L.D.M., Cruzeiro, A. L. S. ve Pinheiro, R. T. (2007). Psychological well-being and adolescence: associated factors. Cadernos De Saúde Pública, 23(5), 1113-1118.

Spilka, B. ve Mullin, M. (1977). Personal religion and psychological schemata: A research approach to a theological psychology of religion. Character Potential: a Record of Research, 8(2), 57-66.

Stoeber, J. ve Corr, P. J. (2016). A short empirical note on perfectionism and flourishing. Personality And Individual Differences, 90, 50-53. 
Telef, B. B. (2013). Psikolojik iyi oluş ölçeği: Türkçe'ye uyarlama, geçerlik ve güvenirlik çalışması. Hacettepe Üniversitesi Ĕ̆itim Fakültesi Dergisi, 28(3), 374- 384.

Terzi, Ş. (2008). Üniversite öğrencilerinde kendini toparlama gücünün içsel koruyucu faktörlerle ilişkisi. Hacettepe Üniversitesi Ĕ̆itim Fakültesi Dergisi, 35, 297306.

\section{Kaynakça Bilgisi / Citation Information}

Bozgeyikli, H. ve Çalışkan, M. (2020). ). Ortaöğretim öğrencilerinin psikolojik iyi oluşlarının yordayıcısı olarak iyimserlik-kötümserlik düzeyi ve dini yönelimler. OPUS-Uluslararası Toplum Araştırmalarn Dergisi, 16(28), 909-928. DOI: 10.26466/opus.734018 